\title{
Petrogenesis and depositional environment of paleozoic Sedili and Pengerang Volcaniclastics in East Johor Basin, Peninsular Malaysia
}

\author{
Sugeng Sapto Surjono ${ }^{*}$, Mohd. Shafeea Leman $^{2}$, Che Aziz Ali ${ }^{2}$, Kamal Roslan Mohamed ${ }^{2}$, and Fathan Hanifi Mada $\mathrm{M}^{1}$ \\ ${ }^{1}$ Department of Geological Engineering, Faculty of Engineering, Universitas Gadjah Mada, Jl Grafika No.2, Yogyakarta, 55281, Indonesia \\ ${ }^{2}$ Geology, School of Environmental and Natural Resource Sciences, Faculty of Science and Technology, Universiti Kebangsaan Malaysia, \\ 43600 UKM Bangi, Selangor, Malaysia
}

\begin{abstract}
Volcaniclastic rocks in East Johor Basin are found in a relatively great abundance comprising Sedili and Pengerang Formations excluding the metamorphics, siliciclastics, and granites. Since the volcaniclastic rocks are found in a different formation, this study aims to find out the characteristics of each rock. Geology, petrography, and geochemical analyses were elaborated to reveal the petrogenesis and depositional environment in the studied area on the basis of fieldwork data and 24 samples collected from outcrops. The Sedili and Pengerang Formations are dominated by acidic rocks of rhyolite, rhyodacite, ignimbrite, and lava classifiied into calc-alkaline magma series which indicates a subduction-related product. Moreover, those acidic rocks are grouped into active continental margin. Eventhough volcanic rocks in Sedili and Pengerang Formations exhibit similar characteristics, they are different in several major contents. Therefore, it is inferred that both Sedili and Pengerang Formations were deposited in different phase. Coincidentally, depositional environment of both formations is also distinct. Sedili Formation were deposited in the subaerial to shallow marine, meanwhile, Pengerang Formation is interpreted to be deposited in deeper depositional setting.
\end{abstract}

\section{Introduction}

\subsection{Geological background}

East Johor Basin basically lies in East Malaya region which is one of the continental blocks that established Southeast Asian mainland [1]. A collision between this continental block and Indochina terrane toward Sibumasu (western part of East Malaya) during Middle to Late Triassic time yielded Peninsular Malaysia [2,3]. In addition, traditionally, the Peninsular Malaysia is split up into three parts: Western, Central, and Eastern Belts. This division suits to Scivenor (1928) who classified it into Eastern Tin, Central Gold, and Western Tin Belts [4]. The Eastern Belt, which is mostly formed by Paleozoic rocks, is divided into two subregions: Terengganu region in the north and East Johor region in the south. Paleozoic volcanic rocks in East Johor Basin, which are Sedili and Pengerang Formations, mostly comprise of volcaniclastic rocks, rhyodacitic and andesitic lava, and resedimented volcaniclastic deposits. According to Surjono, the Sedili Formation is mostly distributed relatively northern part of Johor Basin in the Gunung Sumalayang, Sungai Ulu
Sedili and Gunung Chemendong areas [5]. The formation interfingers with the Dohol and Linggiu Formations (Figure 1a), thus this formation is thought to be deposited during the Early to Late Permian. The Pengerang Formation is distributed in the southern part of Johor Basin of Pengerang area (Figure 1b). Both of them are interpreted to be contemporaneously deposited, where the Pengerang Formation is probably equivalent to the upper part of Sedili Formation.

\subsection{Paleozoic volcanism of East Johor Basin}

Referring to the Paleozoic stratigraphy which composes the East Johor Basin [5], volcaniclastic rocks are mostly found in all of the formations which comprise the East Johor Basin. However, the product of Paleozoic Volcanism of East Johor Basin is well-recorded either in Sedili or Pengerang Formation. These formations mostly consist of volcanic rocks and lava [6]. The initial volcanism is predicted to be in Early Permian contemporaneously with the deposition of Dohol Formation which is interfingered with Sedili Formation.

\footnotetext{
* Corresponding author: sugengssurjono@ugm.ac.id
} 


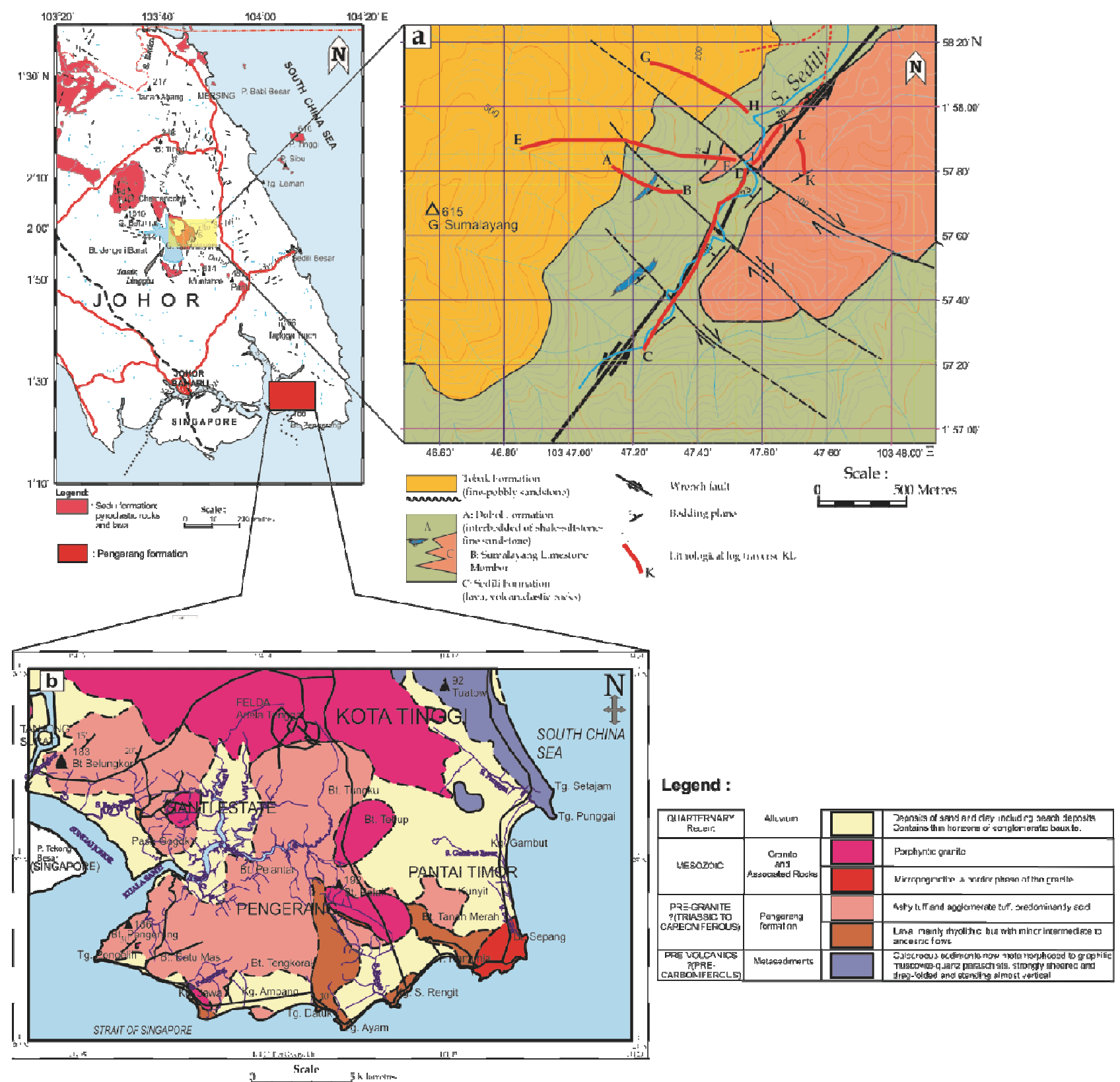

Figure 1. a. Geological map of Sedili area showing the distribution of Sedili Formation [5], b. Geological map of Pengerang (Grubb, 1968, and Singh, 1985 with modification)

The occurrence of these volcanic rocks lies in the Sedili Formation can be found in Gunung Pertawai in northernmost which by Chong et al. are called as Jasin Volcanic [7]. This formation can also be discovered in coastal area of northern Johor, from Tanjung Penyabung to offshore Pulau Sibu.

The Sedili Formation is mostly dominated by volcaniclastic rocks with the minor proportion of lava. These rocks have the characteristics of dark to greenish grey in color, with locally pale grey and pinkish grey, light maroon and black. The volcaniclastic rocks are mainly formed by ignimbrite, welded tuff, fine-grained lapilli, any kind of tuff varieties, volcanic ash, agglomerate, and volcanic breccia. Most of outcrops found in study area are massive with a few tiny stratified rocks. In Gunung Sumalayang area, tuff varieties are more dominant than other volcanic rocks. The tuff is commonly formed by fine-to coarse ash, fine-grained lapilli, crystal and lithic fragment. Meanwhile, in eastern coast of northern Johor, the volcaniclastic rocks are dominated by agglomerate, volcanic breccia, and ignimbrite.

The thickness of Sedili Formation is actually difficult to be determined because of their large distribution and very thick outcrop establishing a mountain and mountainous range. Rajah in 1986 inferred the maximum thickness of exposed volcanic sequence in Gunung Sumalayang-Gunung Belumut area is about $760 \mathrm{~m}$ [8]. Herein, the volcaniclastic rocks are deposited in association with the siliciclastic sediments of the Dohol Formation. This reflects that material within Dohol Formation probably came from volcaniclastic reworking of Sedili Formation (Figure 1).

On the other hand, volcanic rocks of Pengerang Formation are dominantly distributed in southern tip of Eastern Belt Peninsular Malaysia. Lava can be found in 
several locations including Bukit Buloh-Bukit Hutai, Kampung Ramunia, Kampung Sungai Rengit, and Tanjung Stapa (Figure 1b). Meantime, the volcaniclastic rocks are equally spread out in Belungkor area in the west, Pengerang area in the middle, and Kunyit area in the east. Volcanic rocks of Pengerang Formation are mainly rhyolitic lava flows and volcaniclastic rocks [6]. Nevertheless, Grubb in 1968 reported that andesitic lava was also found in this formation [9]. Lava formed both banded and non-banded structures with dark and colored lava, porphyritic as well as aphanitic textures. Meanwhile, volcaniclastic rocks comprise of ashy tuff and pyroclastrich volcanic breccia. All of Pengerang Formation rocks unconformably overlie metasediment of Mersing Formation. Both of Pengerang and Mersing Formation are equally intruded by Triassic granite, it may be part of Tengkil Granite of Rajah et al. in 1977 [10]. Grubb interpreted volcanic product of East Johor Basin as gradual deposition. First, quiscience period of volcanism result lava flows [9]. Hereinafter, explosive activity occurred in this area and produced pyroclastic rocks.
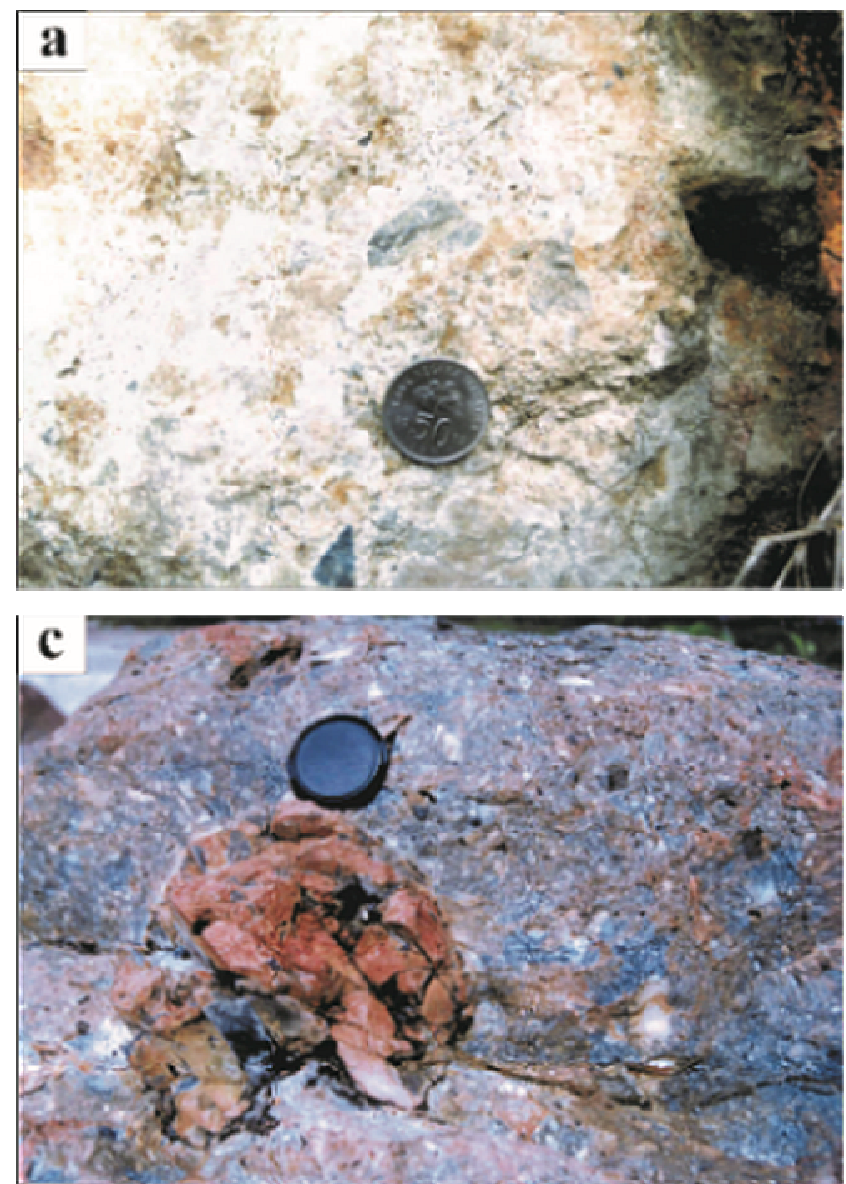

\section{Methods}

Major and trace elements analysis are carried out to understand the petrogenesis of volcanic rocks. These geochemical analysis was done using X-ray fluorescence technique (XRF). It is also utilized to distinguish the characterization of volcanic rocks in Sedili and Pengerang Formations. 10 major elements and 20 trace elements of 24 volcanic rock samples are identified in this study to see the difference of both formations.

Thin sections of volcanic rocks are carried out to see the more detail information on identifying rocks based on mineralogical composition and its percentage, sedimentary structure, texture, and fossil content. All of samples in which had been done geochemical analysis, are then examined using petrographical analysis. These petrographical data are further taken advantages for supporting facies division after facies analysis on stratigraphical unit. The elaboration of petrographical analysis, facies, and stratigraphical succession are used to interpret the depositional environment.
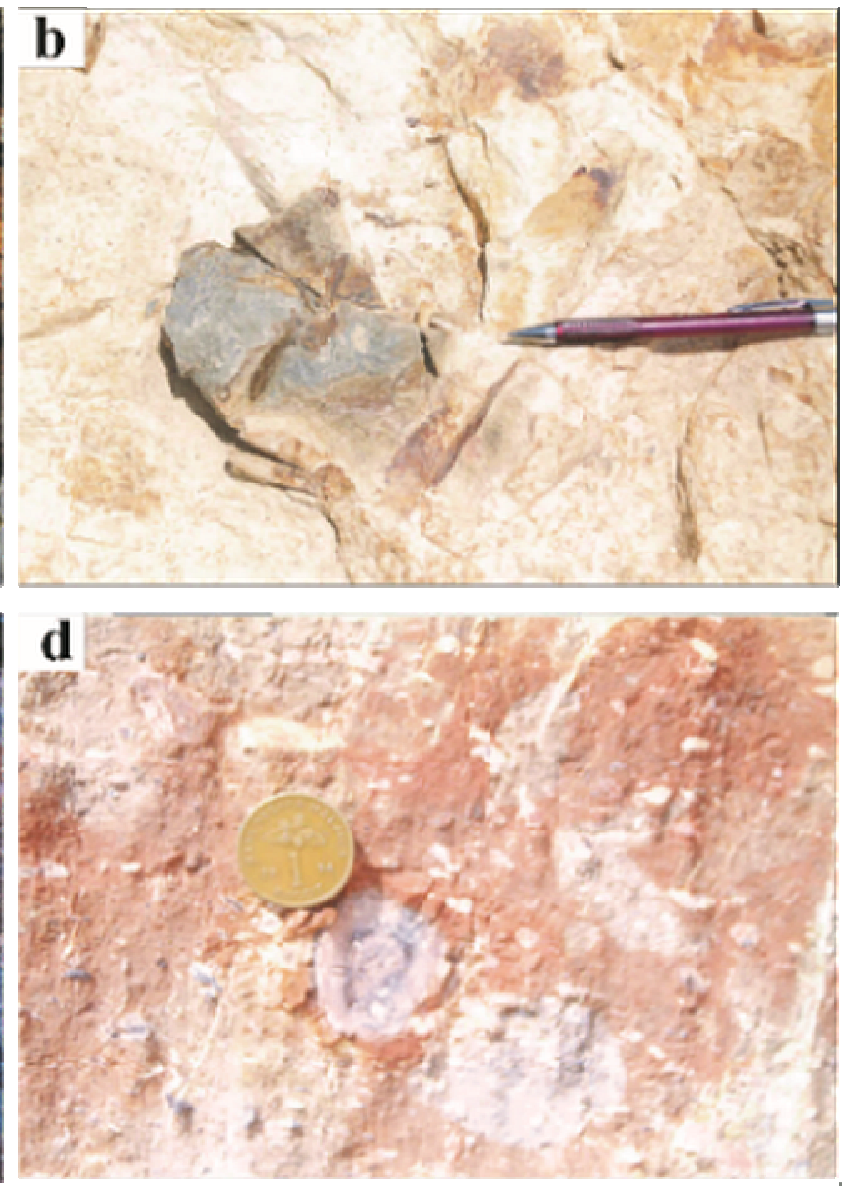

Fig. 2. Photograph of representative outcrops composing the Sedili Formation: a.Volcanic lithic clast within ignimbrite deposit; $b$. Fragment of pyroclastic breccia; c. Bomb fragment in agglomerate of pyroclastic fall deposit; d. Accretionary lapilli and ash of pyroclastic deposit. 


\section{Results}

\subsection{Geology and petrography}

\subsubsection{Sedili volcanic product}

The Sedili Formation is shaped by lava and volcaniclastic, in which lava is less dominant compared to the volcaniclastic rocks deposited during the Early to Late Permian [5]. Two types of volcaniclastics are well recognized. At eastern flank of Gunung Sumalayang, volcaniclastic rocks are represented by fine-to-mediumgrained pyroclastic rocks with bedding structure, whereas those rocks that are discovered in the coast of Mersing at Tanjung Penyabung to Air Papan are characterized by disorganized pyroclastic breccia and agglomerates. Referring to Fisher and Schminke, McPhie et al., [11,12], volcanic textures, structures, and components of volcaniclastic rocks that developed in eastern flank of Gunung Sumalayang can be genetically classified into pyroclastic flow deposits, whilst volcaniclastic rocks in Mersing Area are known as pyroclastic fall. Pyroclastic flow deposits in Sedili Formation comprise of interbedded of fine tuff and fine-grained lapilli, which are silicic. The fine-grained tuff, lapilli and volcanic ash usually form a banded variety with distinctly welded tuff (Figure 2). Typical ignimbrite (Figure 2a) generally grades imperceptibly into crystal, vitric, lithic, and ashy tuff. Based on petrographic analysis, ignimbrite exhibits crystal-vitric type containing mainly large highly corroded, deeply embayed and fractured quartz crystal and few corroded plagioclase and alkali-feldspar phenoclasts. In several samples, a great amount of lithic fragment and rare flattened relict pumice establish the volcanic rocks.

This product can be yielded in association with extrusion of lava domes and lava flows, by collapse of vertical explosive eruption column. It also can occur coming from vents by upwelling and overflow or by low fountaining of pyroclast-gas mixtures [12,13]. Moreover, Fiske and Matsuda inferred that subaqueous pyroclastic flow can occur at the end of a subaqueous eruption [14]. Many of them resemble turbidites and therefore may be remobilized pyroclastic debris originally deposited by fallout or other processes along the shoreline or shallow water flanks of an active volcano. From this, Sedili rocks are inferred depositing in this kind of environment (subaqueous) due to their association with Dohol shallow marine sediments.

On the other hand, pyroclastic fall deposits in northern Mersing coastal has coarser grain than pyroclastic flow in Gunung Sumalayang. It consists of pyroclastic breccia and agglomerate. The fragment of breccia are mostly coarse lapilli and tuff. The grain size can reach until ten centimeters. They are well discovered in Tioman Darat, Kampung Mawar, and Tanjung Resang areas, whereas, agglomerate is vastly distributed in Tanjung Arong Baharu, Tanjung Selantai, and Air Papan areas. Ignimbrite is also found here with minor abundance, sometimes it grades into pyroclastic breccia.

Volcaniclastic deposits in the North Mersing coastal are characterized by relatively low density of pumice lapilli and ash, in which it is transported within the highvelocity jet and eventually deposited by fallout from the connecting plume and umbrella region. That is why this deposit are categorized as a product of pyroclastic fall of Plinian eruption type [14]. Besides that, accretionary lapilli within ignimbrite are identified in northern Mersing coast (Figure 2d).

Petrographically, volcaniclastic crystal particles mainly consist of quartz, alkali feldspar and plagioclase. The average of quartz content ranges from $15 \%$ to $35 \%$, alkali feldspar (mainly orthoclase) varies from 10 to $20 \%$ and plagioclase varies from $20 \%$ to $30 \%$. While, according to pyroclastic rocks classification proposed by Pettijohn in 1975 [16], volcaniclastic rocks in Sungai Sedili area can be classified into crystal vitric tuff and lithic tuff. Tuff content within the rocks ranges from $8 \%$ to $35 \%$ and lithic component varies from $10 \%$ to $35 \%$. Crystal vitric tuff has grain size ranging from clay size to $0.85 \mathrm{~mm}$. It consists of $30 \%$ plagioclase which is clear in color, has broken shape, and partly change to sericite and corroded crystal. While the abundance of orthoclase within the rocks are about $10 \%$. It has Carlsbad twinning and in places change to sericite. While the abundance of quartz, lithic, and tuff are about $15 \%, 10 \%$, and $35 \%$ respectively. On other hand, lithic tuff has grain size varying from $0.01-4 \mathrm{~mm}$. It is mainly composed by lithic of accidental clast of volcanic rocks. It occupies about $35 \%$ of the whole rocks and it is subangular in shape. Whilst, the component of plagioclase, quartz, and tuff are $20 \%, 15 \%$, and $30 \%$ respectively (Figure 3 ).

\subsubsection{Pengerang volcanic products}

Character of volcanic rocks in Sedili and Pengerang Formation are different. Volcanic rocks of Pengerang Formation mainly consist of rhyolitic lava and volcaniclastic rocks. The upper part of rhyolitic lava has been weathered to be residual bauxite (Figure 4). Lava in Pengerang Formation is divided into four distinct lithological types [9] that are andesite, dark non-banded rhyolite, banded porphyritic rhyolite and banded felsic rhyolite. 

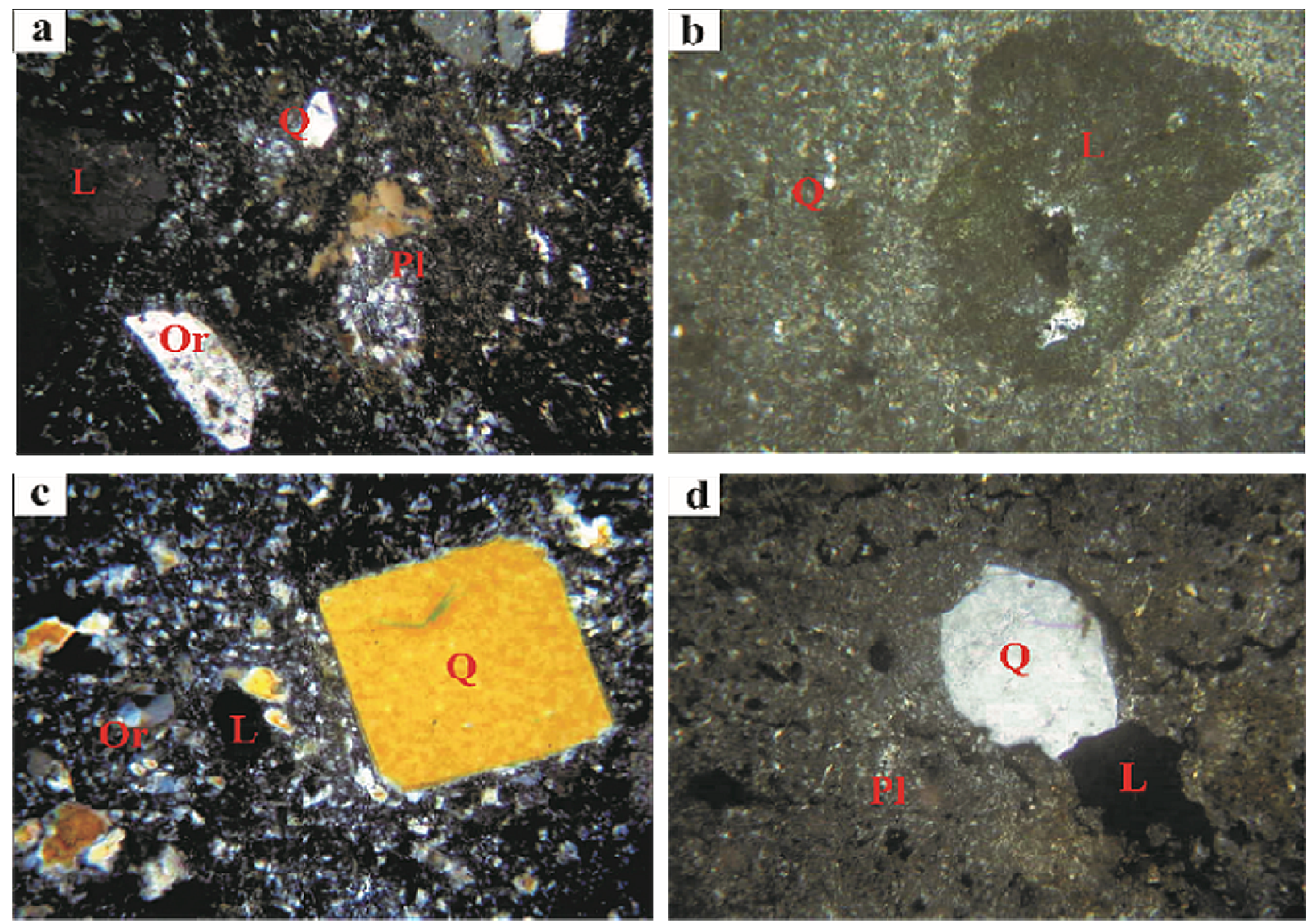

\section{$0.3 \mathrm{~mm}$}

Fig. 3. Thin section examined from 4 samples from the Sedili Formation a. Crystal vitric tuff examined in rhyolite with pyroclastic texture mainly composed of plagioclase, quartz, and tuff; b. Dacite, mainly composed by lithic, plagioclase, \& tuff; c. Rhyolite, mainly composed by quartz \& plagioclase d. Dacite mainly composed by tuff, plagioclase, and quartz.

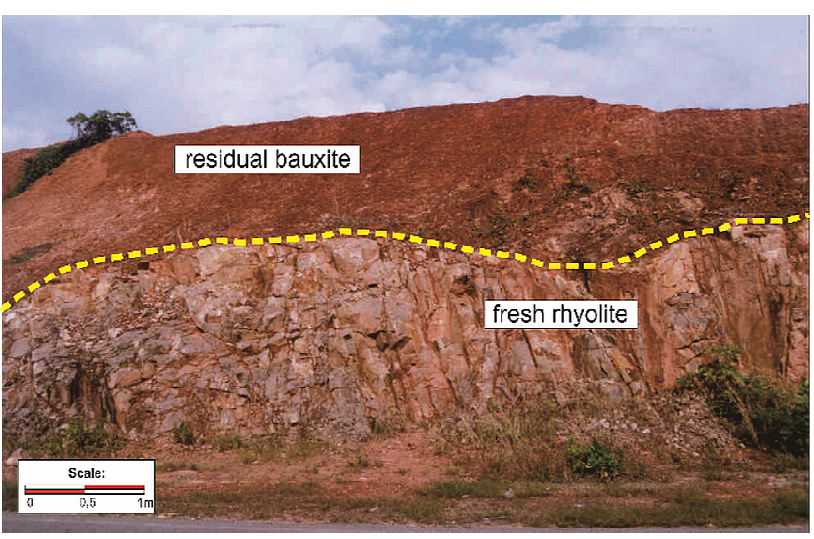

Fig. 4. Pengerang outcrop representative showing the dark nonbanded rhyolite as a parent rock for bauxite.

Andesite in Pengerang Formation was introduced by Grubb (1968) as small section of pillow lava at the coast of Tanjung Bulat and as a slab-like xenolith in micropegmatite at the periphery of granite intrusion [9]. Herein, lava is usually vesicular with subordinate scoriaceous. The color are black to dark grey. The vesicles are generally filled by albite, epidote, and chlorite. Apart of the lava, volcanic rocks are also found in Pengerang area. Volcaniclastic rocks of Pengerang Formation mainly comprise of ash tuff and pyroclast-rich breccia to pyroclast-rich lapillistone which are acidic in composition. These volcanic rocks are more numerous than lava in Pengerang area. They also form undulating morphology with several isolated hills such as the Bukit Belungkor (183 m), Bukit Pengerang (186 m), Bukit Peali (192 $\mathrm{m})$ and the smaller neighboring hills.

Petrographically, lava, and volcaniclastic rocks in Pengerang Formation are dominated by rhyolite. However, there are a few differences between dominant particles composing lava and volcaniclastic rocks. The average of quartz mineral content in lava is $8.4 \%$ to 16.6 $\%$, whereas in volcaniclastic rock is $6 \%$ to $33 \%$. Alkali feldspar (mainly orthoclase) in lava exceeds $50 \%$ while in volcaniclastic is only $2-9 \%$, and plagioclase varies from $1 \%-2.5 \%$ in lava and $0.4 \%-10 \%$ in volcaniclastic rocks (Figure 5). On other hand, according to pyroclastic rocks classification proposed by Pettijohn (1975), volcaniclastic rocks in Pengerang Formation can be classified into crystal lithic tuff with average tuff content about $20 \%$ to $88.6 \%$ and lithic component is about $8 \%$ to $10 \%$ [16]. Rhyolite lava has hypidiomorphic granular texture with subordinate phaneric equigranular, perthitic structure, and medium-grained phenocrysts. The crystal exhibit subhedral-euhedra form. Orthoclase mostly altered into sericite. Hornblende present in some places and altered into chlorite. Other minor mineral within the rock under petrographic section are iron oxide $(1.4 \%)$ and biotite $(0.6 \%)$. Whereas, rhyolite crystal tuff within the formation has fine to medium size $(0.05-1.5 \mathrm{~mm})$. Some samples show welded structure. 

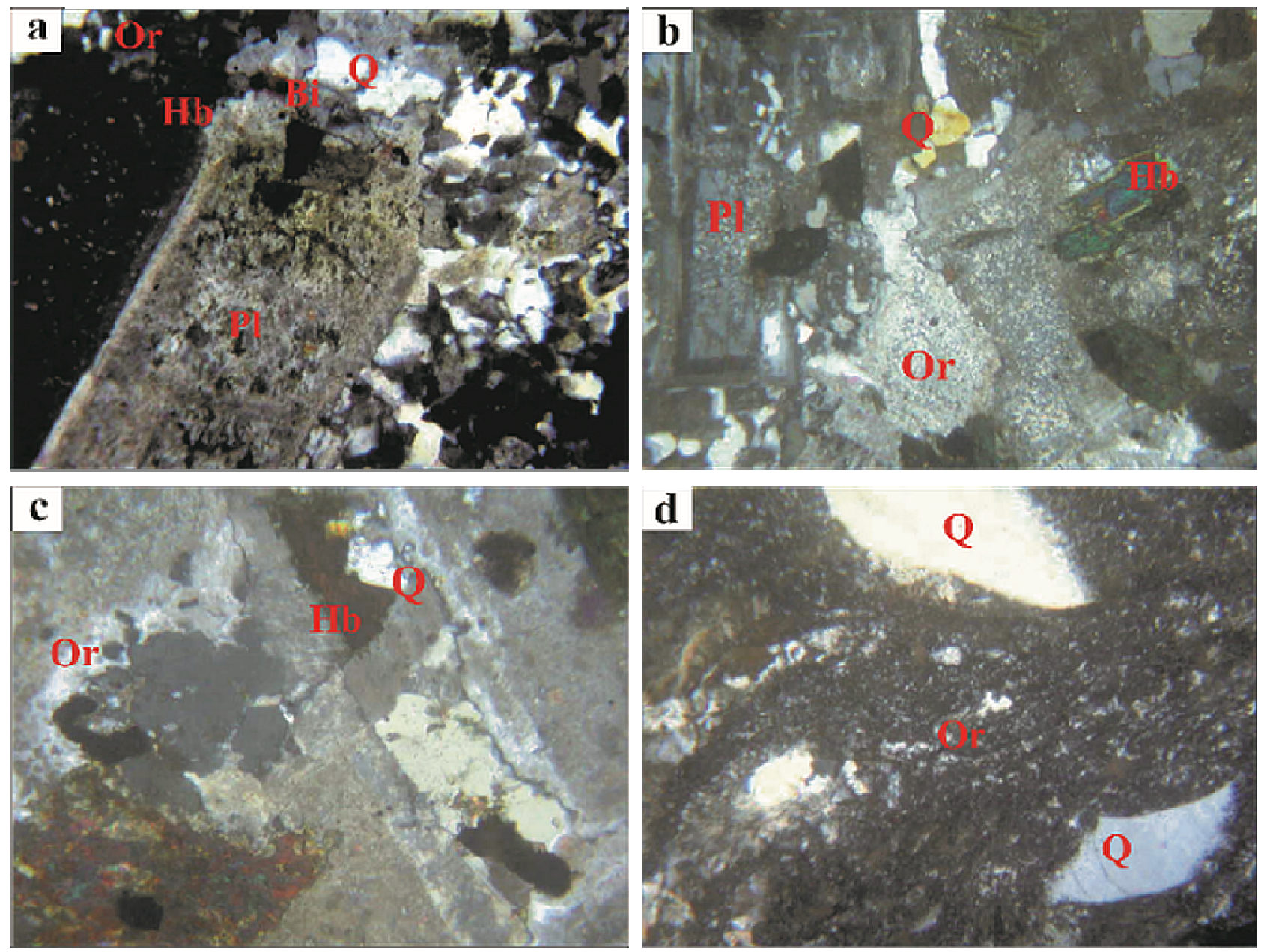

Figure 5. Photomicrograph of Pengerang samples a. Rhyolite with hipidiomorphic texture, perthitic structure, and medium grained phenocryst; b. Rhyolite with hypidiomorphic granular, phaneric equigranular, perthithic structure, medium-grained; c.Rhyolite with hypidiomrphic granular, medium grain size with subhedra-euhedra form; d.Rhyolite with pyroclastic texture, welded structure, with fine-medium grain

\section{Geochemistry}

Result of major element geochemical analysis are listed in Table 1. All samples in Pengerang Formation were taken from Pyroclastic rocks, whilst rock samples in Sedili Formation were taken from the combination of lava and pyroclastic rocks. Pyroclastic rocks of Sedili Formation contain $\mathrm{SiO}_{2} 69.54 \%$ - 79.60\% in weight percentage, $\mathrm{Al}_{2} \mathrm{O}_{3}$ is $12.94 \%$ in weight percentage average, $\mathrm{Fe}_{2} \mathrm{O}_{3}$ has an average weight of $1.91 \%, \mathrm{Na}_{2} \mathrm{O}$ is about $2.51 \%$, and $\mathrm{K}_{2} \mathrm{O}$ is about $3.93 \%$ in weight percentage average. Other major elements including $\mathrm{TiO}_{2}, \mathrm{MnO}, \mathrm{CaO}, \mathrm{MgO}, \mathrm{P}_{2} \mathrm{O}_{5}$ have an average weight below $1.5 \%$. On the other hand, volcanic rocks in Pengerang Formation contain a higher average weight $\mathrm{Al}_{2} \mathrm{O}_{3}$ in comparison with the Sedili Formation which is counted $15.82 \%$. Here, $\mathrm{SiO}_{2}$ ranges from $59.61 \%$ to $79.08 \%$. While average weight percentage of $\mathrm{Na}_{2} \mathrm{O}$ and $\mathrm{K}_{2} \mathrm{O}$ are $3.87 \%, 4.63 \%$ respectively. Lava in Pengerang Formation has evenly smaller $\mathrm{Al}_{2} \mathrm{O}_{3}$ and higher $\mathrm{Fe}_{2} \mathrm{O}_{3}$ compared to the pyroclastic rocks of Pengerang Formation (see Table 2 for more detail). Similarly, the average content of $\mathrm{TiO}_{2}$, $\mathrm{MnO}, \mathrm{MgO}$, and $\mathrm{P}_{2} \mathrm{O}_{5}$ within Pengerang Formation also below $1.5 \%$. Low content of $\mathrm{MgO}$ in both formations indicate that the rocks are felsic. Whereas the relatively high content of $\mathrm{Al}_{2} \mathrm{O}_{3}$ and $\mathrm{K}_{2} \mathrm{O}$ within the formation indicate that chemical character of rocks forming mineral such as feldspar and mica still remain in those rocks. Moreover, low content of $\mathrm{CaO}, \mathrm{Na}_{2} \mathrm{O}, \mathrm{MnO}$, and $\mathrm{P}_{2} \mathrm{O}_{5}$ are response to alteration and weathering level within both the Sedili and Pengerang Formation [17].

According to TAS diagram of volcanic rocks [18], lava and pyroclastic rocks in Sedili and Pengerang Formation can be classified into acidic rocks. 3 out of 24 samples resulted in trachytic rocks due to the low content of $\mathrm{SiO}_{2}$. Rajah (1986) determined some of volcaniclastic rocks of Sedili Formation are rhyodacite though they occasionally grade into dacite-basic andesite, while lava are dominantly rhyolite, quartz latite, and rhyodacite [8]. On other hand, lava of Pengerang Formation in present study that can be found in Pengerang area is more variable in composition than those volcaniclastic in Pengerang as well as in Teluk Belungkor (Figure 6).

In order to obtain the petrogenesis information, major elements data are plotted in several scattered diagrams. It is aimed to understand the difference between volcanic rocks characteristic and their chemical composition and 
distribution. Thereby, data plotting on scattered diagram of $\mathrm{SiO}_{2}$ against $\mathrm{K}_{2} \mathrm{O}[19,20]$ is done. As a whole, volcanic rocks of Pengerang Formation are calc-alkaline series with a medium potassium content. Meanwhile, Sedili Formation is chiefly calc-alkaline series but potassium content within the rocks are lower compared to those in Pengerang Formation. It possibly indicates that both of formation are genetically different. Herein, some of the samples are extremely high in $\mathrm{SiO}_{2}$ and $\mathrm{K}_{2} \mathrm{O}$ content, thus those are plotted beyond the classification. But the trend shows that those are still part of cal-alkaline series. The plotting which shows calc-alkaline series can be interpreted as a convergent margin setting [21]. To support the plotting in $\mathrm{SiO}_{2}$ vs $\mathrm{K}_{2} \mathrm{O}$ diagram, metaluminous-peraluminous scattered diagram of Maniar and Piccoli (1989) is also carried out to distinguish volcanic rocks within the formation [22] (Figure 7).

Table 1. Major elements of Sedili Formation pyroclastic rocks in studied area.

\begin{tabular}{|c|c|c|c|c|c|c|c|c|c|c|c|c|c|c|c|}
\hline \multirow{2}{*}{ Component } & LGU-1 & LGU-9 & Pb-1 & $\mathrm{Pb}-2$ & Rs-1 & Rs-2 & Rs-3 & Ap-2 & Ap-3 & Ap4 & Ap-5 & TJJ-1 & TJJ-2 & TJ 3 & TJJ-4 \\
\hline & Pyro & Pyro & Pyro & Pyro & Pyro & Pyro & Pyro & Pyro & Pyro & Pyro & Pyro & Pyro & Pyro & Pyro & Pyro \\
\hline \multicolumn{16}{|c|}{ Major element (\%) } \\
\hline SiO: & 79.20 & 74.21 & 74.84 & 78.50 & $76.2 C$ & 79.60 & 77.90 & 74.01 & 75.01 & 74.35 & 69.54 & 75.15 & 75.22 & 74.98 & 77.47 \\
\hline TiO: & 0.31 & 0.11 & 0.17 & 0.14 & 0.15 & 5. 17 & 0.25 & 0.18 & 0.38 & 0.15 & 0.42 & 0.25 & 0.20 & 0.12 & 0.22 \\
\hline $\mathrm{Al}_{2} \mathrm{O}_{2}$ & 12.15 & 12.41 & 13.90 & 13.51 & 12.43 & 12.56 & 13.03 & 12.94 & 11.70 & 13.15 & 18.38 & 13.23 & 14.23 & 1284 & 7.68 \\
\hline $\mathrm{Fez}=\mathrm{g}$ & $1.5 \mathrm{C}$ & 1.13 & 2.18 & 2.06 & 2.07 & 1.25 & 1.39 & 2.76 & 4.27 & 1.70 & 1.46 & 1.02 & 0.67 & $2.4 E$ & 2.87 \\
\hline litno & 0.01 & 0.03 & 0.00 & $0.0^{\circ}$ & 0.04 & 2.00 & 0.00 & 0.11 & 0.03 & 0.03 & 0.00 & 0.00 & 0.00 & 0.02 & 0.08 \\
\hline lifgo & $1.7 \mathrm{C}$ & 0.02 & 0.21 & $0.4^{\prime}$ & 0.39 & 0.50 & 0.53 & 0.52 & 0.67 & 0.12 & 0.93 & 0.01 & 0.25 & $0.2 E$ & 0.48 \\
\hline $\mathrm{CaO}$ & $0.0 E$ & 0.41 & 0.08 & 0.02 & 1.43 & 2.05 & 0.04 & 0.43 & 0.23 & 0.21 & 0.11 & 0.00 & 0.15 & $0.0 E$ & 3.80 \\
\hline$N a: O$ & $0.4 E$ & 3.82 & 2.39 & 0.72 & 2.55 & 1. 30 & 1.73 & 4.68 & 2.38 & 4.13 & 0.93 & 5.84 & 2.71 & $3.2 E$ & 0.84 \\
\hline $\mathrm{K}=\mathrm{O}$ & $3.5 \mathrm{C}$ & 5.42 & 3.70 & 3.03 & 4.02 & 2.04 & 3.39 & 4.35 & 4.40 & 3.85 & 4.09 & 4.74 & 5.02 & 3.84 & 3.87 \\
\hline $\mathrm{P}=\mathrm{O}$ & $0.0 E$ & 0.03 & 0.01 & 0.02 & 0.06 & 3.00 & 0.01 & 0.06 & 0.08 & 0.01 & 0.07 & 0.04 & 0.03 & 0.04 & 0.08 \\
\hline LOI & 2.93 & 0.73 & 2.99 & 2.03 & 2. 18 & 3.77 & 2.75 & 1.34 & 2.24 & 1.64 & 4.92 & 1.43 & 1.68 & $1.3 E$ & 5.05 \\
\hline Iotal & 101.8 & 98,39 & 100.55 & 100.51 & $101 . \overline{2}$ & 121.25 & 101,02 & 101.38 & $10: 39$ & 99.14 & 100.85 & 101.80 & 100.16 & 9225 & 102.35 \\
\hline
\end{tabular}

Table 2. Major elements of Pengerang Formation pyroclastic rocks in studied area.

\begin{tabular}{|l|l|l|l|l|l|l|l|l|l|l|l|}
\hline \multirow{2}{*}{ Component } & P-2 & P-3 & P-4 & P-5 & P-6 & P-7 & P-8 & B-1 & B-2 & B-3 & B-4 \\
\cline { 2 - 12 } & Lava & Lava & Lava & Lava & Lava & Lava & Lava & Pyro & Pyro & Pyro & Pyro \\
\hline Major element (\%) \\
\hline SiO2 & 75,73 & 71,2 & 72,88 & 62,63 & 59,61 & 70,44 & 68,05 & 71,85 & 63,64 & 70,62 & 75,23 \\
\hline $\mathrm{TiO} 2$ & 0,14 & 0,31 & 0,21 & 0,60 & 0,83 & 0,25 & 0,22 & 0,17 & 0,21 & 0,07 & 0,10 \\
\hline $\mathrm{Al} 2 \mathrm{O} 3$ & 13,15 & 13,3 & 12,65 & 16,70 & 18,27 & 17,06 & 19,34 & 14,58 & 23,02 & 17,34 & 12,77 \\
\hline $\mathrm{Fe} 2 \mathrm{O} 3$ & 0,91 & 4,26 & 3,06 & 6,33 & 6,68 & 2,96 & 2,76 & 2,29 & 2,68 & 1,88 & 1,35 \\
\hline $\mathrm{FeO}$ & 0,00 & 0,00 & 0,00 & 0,00 & 0,00 & 0,00 & 0,00 & 0,00 & 0,00 & 0,00 & 0,00 \\
\hline $\mathrm{MnO}$ & 0,03 & 0,10 & 0,08 & 0,18 & 0,18 & 0,08 & 0,08 & 0,07 & 0,09 & 0,10 & 0,05 \\
\hline $\mathrm{MgO}$ & 0,45 & 0,21 & 0,55 & 0,48 & 0,93 & 0,20 & 0,00 & 0,14 & 0,61 & $-0,10$ & 0,00 \\
\hline $\mathrm{CaO}$ & 0,44 & 0,85 & 1,01 & 2,78 & 3,52 & 0,93 & 1,42 & 1,03 & 1,49 & 2,18 & 0,46 \\
\hline $\mathrm{Na} 2 \mathrm{O}$ & 2,79 & 3,54 & 4,20 & 5,26 & 5,01 & 4,26 & 3,47 & 3,56 & 3,26 & 3,66 & 3,47 \\
\hline $\mathrm{K} 2 \mathrm{O}$ & 5,58 & 4,85 & 4,26 & 3,81 & 3,34 & 4,40 & 3,79 & 5,30 & 4,00 & 4,41 & 5,89 \\
\hline $\mathrm{P} 2 \mathrm{O} 5$ & 0,09 & 0,02 & 0,04 & 0,23 & 0,23 & 0,02 & 0,05 & 0,07 & 0,11 & 0,01 & 0,01 \\
\hline LOI & 0,69 & 0,35 & 0,65 & 1,14 & 0,97 & 0,93 & 0,82 & 1,90 & 0,90 & 0,84 & 0,68 \\
\hline Total & 100,00 & 99,1 & 99,59 & 100,14 & 99,57 & 101,53 & 100,00 & 100,96 & 100,00 & 101,01 & 100,0 \\
\hline
\end{tabular}




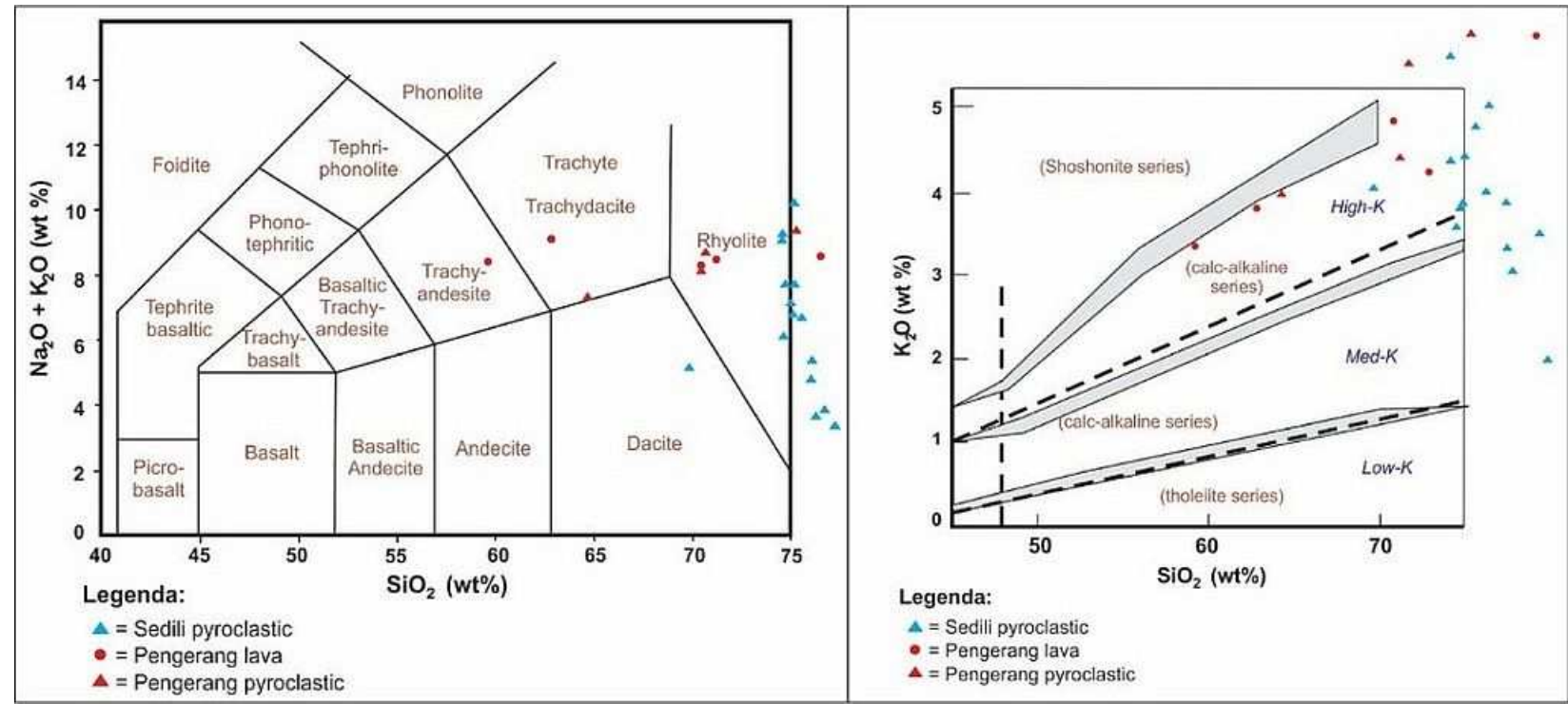

Fig. 6. Geochemical composition diagram a.) $\mathrm{SiO}_{2}$ against $\mathrm{Na}_{2} \mathrm{O}+\mathrm{K}_{2} \mathrm{O}$ diagram of volcanic rocks in studied area [12] b.) $\mathrm{SiO}_{2}$ against $\mathrm{K}_{2} \mathrm{O}$ diagram [13,24].

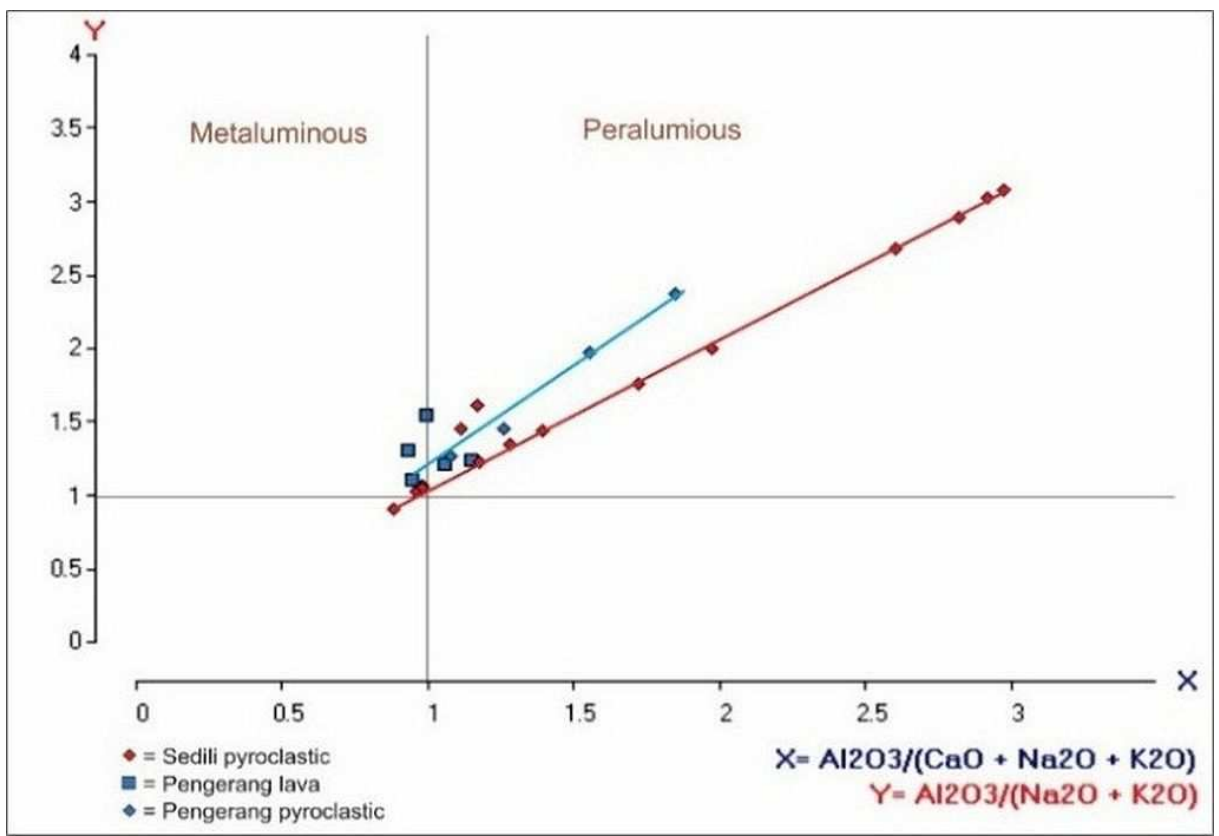

Fig. 7. Classification diagram $\mathrm{Al} 2 \mathrm{O} 3 /(\mathrm{Na} 2 \mathrm{O}+\mathrm{K} 2 \mathrm{O})$ vs $\mathrm{Al} 2 \mathrm{O} 3 /(\mathrm{CaO}+\mathrm{Na} 2 \mathrm{O}+\mathrm{K} 2 \mathrm{O})$ [15].

According to this, ASI $\left(\mathrm{Al}_{2} \mathrm{O}_{3} / \mathrm{CaO}+\mathrm{Na}_{2} \mathrm{O}+\mathrm{K}_{2} \mathrm{O}\right)$ in mol \%) value of both formations exhibit low peraluminous (ASI $=0.75-1.14)$ to strong peraluminous $(\mathrm{ASI}=1.2-1.5)$ characters. Those have different trend each other, in which Sedili Formation has evenly higher ASI value than that in Pengerang Formation. Perhaps, it portrays different level of magma fractionation.

\section{Discussions}

A thorough study is interesting to be carried out to examine the difference of volcaniclastic genesis in East Johor Basin. Rocks in studied area can be classified as magmatism product due to $\mathrm{Ti}, \mathrm{Mg}$, and $\mathrm{Fe}$ content [17]. It is also empowered by petrographical analysis which shows feldspar and quartz relict.
According to geochemical analysis above, volcanic rocks in Pengerang and Sedili Formation show only a little different characteristic. Although both of them are dominated by calc-alkaline rocks, Sedili volcanic has wider range of potassium content compared to Pengerang Formation. Miyashiro (1974) reported that the increase in the proportion of CA (calc-alkaline) series magma is caused by progressive depletion of the upper mantle wedge overlying a descending slab [23].

Referring to Jakes and White (1972), calc-alkaline rocks in active continental margin and island arc are different [24]. Active continental margin has $\mathrm{SiO}_{2}$ content ranging from 50 to $66 \%, \mathrm{~K}_{2} \mathrm{O}$ and $\mathrm{Na}_{2} \mathrm{O}$ ratios vary from 0.60 to 1.1 , and contain a small amount of quartz, garnet and cordierite phenocrysts. Whilst, $\mathrm{SiO}_{2}$ content in island arc ranges from 50 to $66 \%$. It also has $\mathrm{K}_{2} \mathrm{O}$ and $\mathrm{Na}_{2} \mathrm{O}$ ratio less than 0.8 and there is no quartz, garnet, and cordierite phenocrysts presence. In present study, both of 
Sedili and Pengerang Formation has $\mathrm{SiO}_{2}$ content more than $66 \% \quad(75.75 \%$ and $69.77 \%$, respectively). Meanwhile, $\mathrm{K}_{2} \mathrm{O}$ and $\mathrm{Na}_{2} \mathrm{O}$ ratio in Sedili and Pengerang Formation are 1.56 and 1.19 respectively. In addition, quartz, garnet, and cordierite phenocrysts are present within the rocks in both formations. Therefore, Sedili and Pengerang Formations are interpreted to be deposited in active continental margin tectonic setting. Furthermore, both Sedili and Pengerang Formations exhibit low content of $\mathrm{Fe}_{2} \mathrm{O}_{3}, \mathrm{MgO}, \mathrm{CaO}$ and $\mathrm{Cr}$ (Table $1 \& 2$ ). It indicates that magma had undergone differentiation. It is appropriate with Bowen (1928) who reported that in nonalkalic igneous rock series, the $\mathrm{SiO}_{2}, \mathrm{Na}_{2} \mathrm{O}$, and $\mathrm{K}_{2} \mathrm{O}$ contents of magma increased, and the total iron, $\mathrm{MgO}$, and $\mathrm{CaO}$ contents decreased with the rock series formation (basalt-andesite-dacite-rhyolite) [25]. Besides that, low content of $\mathrm{MgO}$ also suitable with rhyolitic rocks within the formation [17]. The decreasing of $\mathrm{MgO}$ level is usually accompanied by the increasing of $\mathrm{SiO}_{2}$ level, it can be caused by contamination by thickened crust as well as of the generation of high silicic magmas by partial melting within the thickened crust [23].

Both Sedili and Pengerang Formations have a similar rocks characteristic. Yet, they are actually different in several aspects. It is based on some major elements content $\left(\mathrm{CaO}, \mathrm{Na}_{2} \mathrm{O}, \mathrm{K}_{2} \mathrm{O}, \mathrm{MgO}, \mathrm{Fe}_{2} \mathrm{O}_{3}\right)$ which exhibit a different value. Although the differentiation is not that significant, it may indicate that volcanic rocks in Sedili and Pengerang Formations were deposited in different phase. Due to $\mathrm{K}_{2} \mathrm{O}$ content in Pengerang Formation higher than that in Sedili Formation, Pengerang volcanic is more calc-alkalic. Thereby, it is interpreted that these rocks underwent more intensive magma differentiation.

The volcanic Sedili is dominated by fine-grained particles indicating that it was deposited far away from the eruption vent. Due to the volcano position around the coastal area, pyroclastic flow deposit occurs as a result of explosive eruption that flow into the shallow marine environment. In northern Mersing coastal area, pyroclastic rocks consist of coarse clasts mainly of volcanic blocks and bombs, pumice, lithic, lapilli, and accretionary lapilli. Those rocks are resulted by fallout of explosive eruption under subaerial depositional environment or may be within very shallow water, probably shallow marine environment. The presence of carbonized wood within ignimbrite show that those rocks are product of volcano eruption in tropical region area. This also indicate subaerial condition when the rocks were deposited. Hereinafter, Sedili Formation is deemed a result of extensive volcanism that took place near the western coast of East Johor Basin the period of Middle to Late Permian. During the Late Permian, this volcanism activity migrated eastward towards subaerial environment, yielding extensive pyroclastic fall. On other hand, Pengerang Formation is inferred to be also deposited in subaqueous environment, but in different depositional setting from Sedili Formation. It is based on lava pillow structure occurrence within the formation which shows that it was deposited in a shallower subaqueous environment [26]. However, the low intensity of this pillow indicate that the lava was emplaced in the relatively shallower than the environment of basaltic pillow lava. Besides that, subaqueous environment of this deposit can also be interpreted from the characteristic of the succession of volcaniclastic deposits. The succession here shows gradually reducing depositional energy represented by changing lithology from pyroclast-rich breccia to the resedimented ash-rich mudstone.

\section{Conclusion}

According to discussion above, volcanic rocks in Sedili and Pengerang area are dominated acidic rocks. Both of them are also classified into calc-alkaline rock series, but potassium content within Sedili Formation is lower than that in Pengerang Formation. It denotes subductionrelated products. Sedili and Pengerang Formations are interpreted depositing in active continental margin tectonic setting. It is interpreted that volcanic rocks in Sedili and Pengerang Formations were deposited in different phase, in which Pengerang Formation underwent more intensive magma differentiation. Sedili Formation which is interpreted to be deposited in the relatively subaerial to shallow marine depositional environment. Pengerang Formation is also inferred depositing in subaqueous environment with a deeper depositional setting.

The authors are grateful to Ministry of Science, Technology, and Innovation of Malaysia for granting this research during first author's pursue $\mathrm{PhD}$ degree. Thank also to Universiti Kebangsaan Malaysia, and Universitas Gadjah Mada for facilitating this study.

\section{References}

1. Metcalfe, I.. Late Paleozoic and Mesozoic palaeogeography of Southeast Asia. Palaeogeography, Palaeoclimatology, Palaeoecology, 87: 211-221. (1991)

2. Hutchison, C.S.. Geological evolution of Southeast Asia. New York: Oxford University Press. (1989)

3. Metcalfe, I. The Evolution of the Malay Peninsula. $J$. Asian Earth Sci. 76 pp.195-213 (2013)

4. Scivenor, J.B.. The geology of Malayan ore-deposit. London, Macmillan. (1928)

5. Surjono, S.S. Stratigraphy and sedimentology of the East Johor Palaeozoic Basin, Peninsular Malaysia. Unpublished doctoral thesis: Faculty of Science and Technology, Universiti Kebangsaan Malaysia (2007)

6. Surjono, S.S., Mohd. Shafee Leman, Che Aziz Ali, Kamal Roslam Mohamed \& Ibrahim Abdullah.. Volcanic rock heritage in the Pengerang area, Johor, Malaysia. In Sutarto, Suprapto, Herwan Lukito, Heru Sigit \& Shafeea Leman (eds.) Geological heritage of Indonesia and Malaysia. Proceeding of Symposium on Geological Heritage 2004, pp. 347-359. (2004)

7. Chong, F.S., Cook, R.H., Evans, G.M. \& Suntharalingan, T.. Geology and Mineral resources of the Melaka-Mersing area, Geological Survey of Malaya Annual Report 1968. pp. 89-94 (1968) 
8. Rajah, S.S. The Geology and mineral resources of the Gunung Belumut Area, Johore. Geological Survey of Malaysia Memoir 19. 191 pp. (1986)

9. Grubb, P.L.C.. Geology and Bauxite Deposits of the Pengerang area, southeast Johor. Geological Survey of West Malaysia District Memoir 14 (1968)

10. Rajah, S.S., Chand, F. \& Singh, D.S. The granitoid and mineralization of the Eastern Belt of Peninsular Malaysia. Geo. Soc. of Malaysia Bulletin 9: 209-232. (1977)

11. Fisher, R.V. \& Schmincke, H.U. Pyroclastic Rocks. Springer-Verlaag (1984)

12. McPhie, J., Doyle, M. \& Allen, R.. Volcanic Textures, $A$ guide to the interpretation of textures in volcanic rocks, Tasmania. (1993)

13. Macdonald, G.A.. Volcanoes. New Jersey: Prentice Hall. (1972)

14. Fiske, R.S. \& Matsuda, T.. Submarine equivalents of ash flows in the Tokiwa Formation, Japan. Geological Society of America Bulletin 80: 1-8. (1964)

15. Walker, G. P. L., Explosive Volcanic Eruptions - a New Classification Scheme. Geol. Rundschau,62, p. 431-446. (1973)

16. Pettijohn, F.G.. Sedimentary rocks. 3rd ed,Harper (1975)

17. Harahap, B.H. Ciri Geokimia Batuan Vulkaniklastika di daerah Tanjung Balit, Sumatra Barat: Suatu Indikasi Kegiatan Magma pada Eosen. Jur. Geo. Ind. Vol.5 No.2: 75-91. (2010)

18. Le Bas, M.J., Le Maitre, R.W., Streickeisen, A., Zanettin, B.. Chem class of vol rocks based on the total alkali-silica diag. J. Petro. 27: 745-750. (1986)

19. Le Maitre, R.W. A Classification of Igneous Rocks and Glossary of Terms: Recommendations of the International Union of Geological Sciences Subcommission on the Systematics of Igneous Rocks, Blackwell, Oxford. (1989)

20. Rickwood. P.C. Boundary line within petrologic diagrams which use oxides of major and minor elements. Lithos vol.22, p. 247-263. (1989)

21. Chin, E.J., Shimizu, K., Bybee, G.M., \& Erdman, M. On the Development of the Calc-Alkaline And Tholeiitic Magma Series: A Deep Crustal Cumulate Perspective, Earth and Planetary Science Letter 482 pp. 277-287 (2018)

22. Maniar, P.D. and Piccoli, P.M. Tectonic Discrimination of Granitoids. Geology Society America Bulletin 101: 635-643. (1989)

23. Miyashiro, A.. Volcanic Rock Series in Island Arcs and Active Continental Margins. America J. of Sci. 274: 321-355. (1974)

24. Jakes, P. and White, A.J.R.. Major and Trace Element Abundances in Volcanic Rocks of Orogenic
Areas. Geo. Soc. of America Bulletin 83: 29-40. (1972)

25. Bowen, N.L.. The Evolution of the Igneous Rocks, N.J, Princeton University Press, 334 p. (1928)

26. Sanchez, C., Sarrionandia, F., Juteau T., \& Ibarguchi, G. Structure and Organization of Submarine Basaltic flows: Sheet Flow Transformation into Pillow Lavas in Shallow Submarine Environment. Geol. Rundschau, 101, pp. 2201-2214 (2012) 